American Journal of Applied Sciences 8 (4): 323-331, 2011

ISSN 1546-9239

(C) 2010 Science Publications

\title{
Using Orthosiphon stamineus B. for Phytoremediation of Heavy Metals in Soils Amended with Sewage Sludge
}

\author{
${ }^{1,2}$ Arifin Abdu, ${ }^{1}$ Najihah Aderis, ${ }^{1,2}$ Hazandy Abdul-Hamid, ${ }^{1}$ Nik Muhamad Majid, \\ ${ }^{3}$ Shamshuddin Jusop, ${ }^{1}$ Daljit Singh Karam and ${ }^{4}$ Khairulmazmi Ahmad \\ ${ }^{1}$ Department of Forest Production, Faculty of Forestry, \\ ${ }^{2}$ Laboratory of Sustainable Bioresource Management, \\ Institute of Tropical Forestry and Forest Products, \\ ${ }^{3}$ Department of Land Management, Faculty of Agriculture, \\ Universiti Putra Malaysia, 43400 UPM Serdang, Selangor, Malaysia \\ ${ }^{4}$ Department of Crop Science, Faculty of Agriculture and Food Sciences, \\ Universiti Putra Malaysia Bintulu Sarawak campus, 97008 Bintulu, Sarawak, Malaysia
}

\begin{abstract}
Problem statement: Phytoremediation is a biological treatment where plants are used to remove pollutants from the environment to make them harmless. A study was conducted in a greenhouse at the Faculty of Forestry, Universiti Putra Malaysia on the potential of Orthosiphon stamineus B. planted in sewage sludge for heavy metals uptake. The objective of this study was to evaluate the ability of $O$. stamineus to remove toxic heavy metals from sewage sludge. Approach: A total of 36 of O. stamineus were treated at six different levels of soil mixture and sludge treatment including one control. The treatments were replicated six times. Growth parameters mainly height and basal diameter were measured for each plant within 10 weeks. Soil texture (pipette method), soil pH (glass-electrode method) and total carbon (C) (Los on Ignition) were determined. The concentration of heavy metals that include cadmium $(\mathrm{Cd})$, chromium $(\mathrm{Cr})$, zinc $(\mathrm{Zn})$, copper $(\mathrm{Cu})$ and lead $(\mathrm{Pb})$ in the planting media and plant parts were analyzed using Inductively Coupled Plasma-Mass Spectrometry (ICP-MS). Results: There was a significant difference $(\mathrm{P} \leq 0.05)$ in height, basal diameter and number of leaves among the six treatments. The height increment values for all treatments in descending order are: T3 $(10.22 \mathrm{~cm}), \mathrm{T} 2(12.42 \mathrm{~cm}), \mathrm{T} 1$ $(13.92 \mathrm{~cm})$, T5 $(14.65 \mathrm{~cm})$, T4 $(16.20 \mathrm{~cm})$ and $\mathrm{C}(16.97 \mathrm{~cm})$. In terms of basal diameter, the highest incremental values in ascending order are T5 $(0.99 \mathrm{~mm}), \mathrm{T} 1(1.20 \mathrm{~mm}), \mathrm{T} 3(1.31 \mathrm{~mm}), \mathrm{T} 2(1.38 \mathrm{~mm}), \mathrm{T} 4$ $(1.53 \mathrm{~mm})$ and $\mathrm{C}(1.75 \mathrm{~mm})$. Soil texture for the control is categorized as clay and for T5 is silt loam. Soil reaction is acidic while total carbon ranges from $16.7 \%$ to $61.3 \%$. The concentrations of heavy metals in the planting medium were higher before planting as compared to after planting. For examples, the values for $\mathrm{Cd}, \mathrm{Cr}, \mathrm{Zn}, \mathrm{Cu}$ and $\mathrm{Pb}$ in $\mathrm{T} 5$ (100\% sewage sludge) before planting are $0.18 \mathrm{ppm}, 23.45 \mathrm{ppm}, 290.05$ ppm, $17.07 \mathrm{ppm}$ and $5.33 \mathrm{ppm}$, respectively. The values decreased after planting where $0.13 \mathrm{ppm}$ for $\mathrm{Cd}$, $24.30 \mathrm{ppm}$ for $\mathrm{Cr}, 252.04 \mathrm{ppm}$ for $\mathrm{Zn}, 18.56 \mathrm{ppm}$ for $\mathrm{Cu}$ and $5.96 \mathrm{ppm}$ for $\mathrm{Pb}$ were observed. O. stamineus absorbed heavy metals in the range of $0.01 \mathrm{ppm}$ to $0.57 \mathrm{ppm}$ for $\mathrm{Cd}, 0.08 \mathrm{ppm}$ to $8.48 \mathrm{ppm}$ for $\mathrm{Cr}, 0 \mathrm{ppm}$ to $43.93 \mathrm{ppm}$ for $\mathrm{Zn}, 0.11 \mathrm{ppm}$ to $16.73 \mathrm{ppm}$ for $\mathrm{Cu}$ and $0.01 \mathrm{ppm}$ to $9.05 \mathrm{ppm}$ for $\mathrm{Pb}$ in various plant parts of leaves, stems and roots. Conclusion: Most of the heavy metals taken up by the plants were stored in the leaves, whereas $\mathrm{Zn}$ seemed to be stored in all plant parts. These results indicate that $O$. stamineus has the potential to accumulate heavy metals particularly $\mathrm{Zn}, \mathrm{Pb}$ and hence could be considered as a good phytoremediator species.
\end{abstract}

Key words: Heavy metals, Orthosiphon stamineus, phytoremediation, sewage sludge, phytoremediator species, chemical remediation methods, organic materials, microbial synthesized products, Completely Randomized Design (CRD), physico-chemical analysis

\section{INTRODUCTION}

Phytoremediation is termed as an in-situ or ex-situ engineered use of plants to remove or control contaminant, or to foster contaminants breakdown by microorganisms in plant and used the term to evaluate the plants use to accumulate metals from the groundwater and soil (Schnoor et al., 1995). Jamil et 
al. (2009) explained that phytoremediation techniques required very low costs to carry out. Likewise, (Meagher, 2000; Ahmadpour et al., 2010) studied that this method is widely recognized and accepted as an ecologically responsible alternative to the environmental destructive chemical remediation methods. In addition, this particular technique is considered as an environmentfriendly as it utilizes natural resources such as microorganisms (Jamil et al., 2009). The process of phytoremediation comprises two distinctive physiological processes which are the uptake of heavy metals by the plant or by the root colonizing microbes.

Sewage sludge is a liquid waste containing some solids, undecomposed organic materials and microbial synthesized products. The sludge includes washing water, urine, laundry waste and some other domestic wastes. Bahmanyar and Piradshti (2008) believed that sewage sludge is suitable as fertilizer material because it contains constituents needed by plants for their growth. In addition, Korentajer (1991) found that sewages sludge exhibited high content of nutrients and organic matter which are favourable to be used as soil amendment medium. Untreated sludge and hydrated treated sludge release nitrogen slowly and this benefits the crops. Research done by Singh and Argawal (2007) recorded that application of sewage sludge to soil stimulates the nutrient cycling and reduces the demand on usage of commercial fertilizers. However, establishment of tree on highly contaminated mining waste or soil usually unsuccessful due to the high content of heavy metals that possess characteristics of pollutants and acts as inhibitor to the plant growth performance. Thus, when the metals are released or channeled into the soil, it may cause hazardous effects to the crops and also the consumers who utilize the products produced from the crops. Jones and Johnson (1989) also observed that the levels of heavy metals, such as $\mathrm{Cd}, \mathrm{Mn}$ and $\mathrm{Zn}$, in the soil and plant tissues increased after sewage sludge was applied and contributes to waterway and soil pollution. KabataPendias and Pendias (2001) determined that $\mathrm{Pb}, \mathrm{Cd}, \mathrm{Cr}$, $\mathrm{Hg}, \mathrm{Zn}$ and $\mathrm{Cu}$ are the most common heavy metal contaminants. Therefore, the mobility of these metals in the soil itself creates interest among researchers in the field of ecotoxicology especially on the total capacity uptake of those metals by type of plants examined (Canet et al., 1997; Sánchez-Martin et al., 2004).

Orthosiphon stamineus B., family Lamiaceae, is widely distributed throughout South East Asia and locally known as 'Misai kucing' in Malaysia and Singapore. This medicinal herb can grow up to 1.5 meter height, exhibiting opposite pairs of leaf arrangement, simple, glabrous, lanceolate leaf blade with serrate margin and green in colour. Leng and LaiKeng (2003) described that $O$. stamineus vegetative propagation is via the cutting of the mature stem. The flower of $O$. stamineus is usually white-bluish in colour, campunulate in colour which gives it the cat's whisker structure. Besides that, Chin et al. (2007) and Affendy et al. (2010) found that O. stamineus is used vastly as traditional medicine to treat gallstones, fever and renal stones. To our knowledge, the information available on the potential of $O$. stamineus for accumulating heavy metals is limited or even lacking. Hence, this study was carried out to elucidate the potential of $O$. stamineus for the uptake of heavy metals on soil treated with sewage sludge.

\section{MATERIALS AND METHODS}

The study was conducted at a greenhouse of Faculty of Forestry, University Putra Malaysia ( $2^{\circ} 59^{\prime}$ 18.24" N latitude and $101^{\circ} 42$ ' $45.45^{\prime \prime}$ E longitude) from April 2009 until July 2009. The seedling of $O$. stamineus mother tree collected from Malaysian Agricultural Research and Development (MARDI) were germinated via cuttings of the mature stem and planted in $16 \times 16 \mathrm{~cm}$ polybags. The proportion of growing medium for $O$. stamineus seedling was soil (3): organic materials (2): river sand (1). The seedlings were transplanted into suitable plastic pot $(32.0 \mathrm{~cm}$ height, $106.0 \mathrm{~cm}$ upper diameter, 69.0 lower diameters) which was filled up with the mixture of soil and sewage sludge right after one month.

The experimental design used in this study was a Completely Randomized Design (CRD) and the pots were labeled according to its composition; Control (100\% soil), Treatment 1 (80\% soil and 20\% sewage sludge), Treatment $2(60 \%$ soil and $40 \%$ sewage sludge), Treatment $3(40 \%$ soil and 60\% sewage sludge), Treatment $4(20 \%$ soil and $80 \%$ sewage sludge $)$ and Treatment 5 (100\% sewage sludge.

The height and diameter of $O$. stamineus planted was measured every 2 weeks during the study period using diameter tape while the basal diameter was measured using venier caliper every 2 weeks. All the dead leaves were collected and kept for analysis in the laboratory. Root rot, infestation of insects, pathogen attack, nutrient deficiency and any abnormalities were jotted down.

Soil samples from each pot were collected before and after planting and kept in standard plastic containers and were air-dried before their physicochemical analysis. The texture of the soil in each pot was determined according to pipette method. Soil $\mathrm{pH}$ 
Am. J. Applied Sci., 8 (4): 323-331, 2011

and total carbon as well as heavy metal concentration $(\mathrm{Cr}, \mathrm{Cd}, \mathrm{Zn}, \mathrm{Cu}$ and $\mathrm{Pb})$ were determined. $\mathrm{pH}$ was determined via glass-electrode at 1:5 soil to solution ratio after reciprocal shaking for 1 hour (Arifin et al., 2007). Total carbon analysis was determined by using conventional method, Los on Ignition (Heiri et al., 2001). Five $\mathrm{g}$ of air-dried soil were kept in oven for 8 hours at $550^{\circ} \mathrm{C}$ and the calculation was carried using the following equation:

Total $\mathrm{C}=[(\mathrm{BO}-\mathrm{AO}) / \mathrm{BO}] \times 100 \%$

Where:

$\mathrm{BO}=$ Soil before oven-dried

$\mathrm{AO}=$ Soil after oven-dried.

ICP-MS was used for digestion of element soluble in aqua regia. One hundred and fifty $\mathrm{ml}$ of concentrated hydrochloric acid were mixed together with $50 \mathrm{ml}$ of concentrated nitric acid gradually in a polypropylene container. Each weighed and grinded samples was placed into the digestion tube and $20 \mathrm{ml}$ of aqua regia was added. The tubes were swirled in a fume hood and left overnight before being heated. Then, the tubes were heated at $80^{\circ} \mathrm{C}$ for an hour before being increasing to $140^{\circ} \mathrm{C}$ for another hour until a clear solution was observed. The hot samples in tubes were left to cool to room temperature before $50 \mathrm{ml}$ of distilled water was added. The samples were then filtered through ash-less medium grade filter study into the plastic bottle. Distilled water was added until $100 \mathrm{ml}$ mark. A blank was prepared for each batch. The sample solution was analyzed by ICP-MS and blank was run accordingly for each batch.

Acid digestion (ICP-MS) was also used to determine the concentration of heavy metals in plant parts. Fresh samples of plant parts were weighed and dried in oven at $60^{\circ} \mathrm{C}$ for 24 hours and shredded into small pieces before digestion. Oven-dried weight was taken to obtain the biomass. Plant biomass was measured separately according to leaves, stems and roots and was calculated. The loss in weight upon drying is the weight originally present. Moisture content is expressed as percentage of the oven-dried weight. The symbol $\mathrm{Pw}$ is used to denote this percentage. The $\mathrm{Pw}$ is the ratio of weight of the samples water to the weight of oven-dried sample multiplied by 100:

$\mathrm{P}_{\mathrm{W}}=[(\mathrm{WW}-\mathrm{DW}) / \mathrm{WW}] \times 100 \%$

Where:

$\mathrm{WW}=$ Wet weight of soil sample

DW $=$ Dry weight of soil sample
All data obtained in terms of growth, heavy metals in soil, sludge and plant parts were subjected to one way Analysis Of Variance (ANOVA). Duncan Multiple Range Test (DMRT) was employed to detect any significant differences among and between the treatments of planting medium and growth parameters such as height, basal diameter and number of leaves. Comparison using t-test also had been done to detect any significant differences between before and after planting.

\section{RESULTS AND DISCUSSION}

General properties of the soils: All treatments were categorized as clay in texture, except for T5 $(100 \%$ sewage sludge) which is silt loam. The percentage of silt ranges from $8.04-56.70 \%$ while the percentage of clay and sand ranges from $20.09-85.15$ and $5.84-25.65 \%$, respectively. Clay and silt loam are termed in fine textured. The results revealed that soil $\mathrm{pH}$ after planting has decreased or became more acidic for all treatments except for $100 \%$ control of soil where the $\mathrm{pH}$ increasing (up to 6.24). The $\mathrm{pH}$ range before planting was from $\mathrm{pH} 5.39$ to 5.98 , while after planting the $\mathrm{pH}$ it was from 4.73 to 6.24 .

This information was useful to identify the deficiency of important nutritional elements in soil samples. Plants need water and nutrients for their growth and the capacity of soils to store water and nutrient increases when their percentage of clay increases. Clay has higher capacity than silt loam to store water and nutrients due to its large surface area. Previous studies had shown that negative charge derived from clay minerals in the soils play important role in determining the soil nutrient or fertility status of acid tropical soils (Arifin et al., 2007). Generally, soil with medium texture (loam) is the most desired for plant growth. After planting soil becomes more acidic because potassium, calcium and magnesium are reduced due to uptake by plants. As the $\mathrm{pH}$ goes above 7 the availability of boron, copper and zinc begins to decline. As such, soil $\mathrm{pH}$ should be kept in the range of 6.4 to 7.0 for good plant growth.

The highest content of total carbon was recorded in T5 which exhibited almost identical range from 0.17 $0.21 \%$. Besides, total carbon was high in all treatments that were treated with sewage sludge indicating that sewage sludge contains higher organic matter compared to the control treatment (mineral soil). Rice (2002) found that the soil fertility improved when organic matter increased. Soil organic matter also improves water holding capacity, thus increasing the plants' ability to withstand short droughts. Kerrigan and Nagel believed that fine textured soil increased the ability of plant to absorb heavy metals. 
Am. J. Applied Sci., 8 (4): 323-331, 2011

Height increment, basal diameter increment and number of leaves of $\boldsymbol{O}$. stamineus: The results showed that there are significant differences $(\mathrm{P} \leq 0.05)$ among the treatments in terms of height increment, basal diameter increment and number of leaves (Table 1). Sewage sludge supplied nutrients such as potassium, magnesium and others to the growing $O$. stamineus which improved the growth. Plant height increased for the first six weeks, after which it leveled off (week 8 to week 10). On the other hand, plant in T5 showed a conspicuous decrease after week 8.

Basal diameter increment showed similar pattern with that of height increment where it increased significantly from week two to eight. After week 8 , the diameter increment was constant for all treatments except for T5 that decreased slightly. It was observed that the control treatment had the highest diameter increment.

Another parameter observed was the increment of leave number where there were significantly different among the treatments. Plant in T2 $(60 \%$ soil; $40 \%$ sewage sludge) showed a conspicuous decrease after week 8 compared to other treatments. The best treatment was T4 (20\% soil; $80 \%$ sewage sludge) which showed higher number of leaves compared to other treatments. The lowest number of leaves was recorded by the control treatment ( $100 \%$ soil), producing only 153 leaves. This is consistent with the finding of Heppner (1993) who showed that environmental condition was the probable cause of leaf dropping.

Biomass of $\boldsymbol{O}$. stamineus plant parts: The plant biomass shows significant difference $(\mathrm{P} \leq 0.05)$ among the treatments where after 10 weeks, treatment $\mathrm{T} 5$ and T3 (40\% soil; $60 \%$ sewage sludge) shows the highest biomass for above ground plant parts; leaves $(84.71 \mathrm{~g})$ and stems $(75.00 \mathrm{~g})$. The lowest biomass was found for plants before planting with values of $35.0 \mathrm{~g}$ for leaves and $37.66 \mathrm{~g}$ for stems.

The average dry weight of root biomass ranges between 82.71 and $98.61 \mathrm{~g}$, while the highest root biomass ranges between 82.71 and $98.61 \mathrm{~g}$ (Table 2). The highest root biomass for below ground was found in the control treatment. In less contaminated soils, factors limiting plant growth are macronutrient deficiencies and physical condition, leading to poor water holding, aeration and root penetration.

Heavy metals concentration in $O$. stamineus growth medium: Table 3 shows the concentration of $\mathrm{Cd}, \mathrm{Cr}, \mathrm{Zn}$, $\mathrm{Cu}$ and $\mathrm{Pb}$ in soil before and after planting. T-test analysis gave significant difference $(\mathrm{P} \leq 0.05)$ of heavy metals in soil between before and after planting $(\mathrm{P} \leq 0.05)$. Plant in treatment T5 recorded the highest $\mathrm{Cd}$ concentration in the planting media with values of 0.18 $\mathrm{mg} \mathrm{kg}-1$ and $0.13 \mathrm{mg} \mathrm{kg}^{-1}$ for before and after planting period, respectively.
Table 1: Height increment, basal diameter increment and number of leaves of $O$. stamineus by 10 weeks

Hight $(\mathrm{cm})$ and basal diameter $(\mathrm{mn})$

\begin{tabular}{llll} 
& & & \\
Treatment & Height & diameter & Leaves \\
\hline Control & $16.97 \mathrm{a}$ & $1.75 \mathrm{a}$ & $153 \mathrm{~d}$ \\
T1 & $13.92 \mathrm{~b}$ & $1.20 \mathrm{~d}$ & $230 \mathrm{c}$ \\
T2 & $12.42 \mathrm{c}$ & $1.38 \mathrm{c}$ & $162 \mathrm{~d}$ \\
T3 & $10.22 \mathrm{~d}$ & $1.31 \mathrm{c}$ & $275 \mathrm{~b}$ \\
T4 & $16.20 \mathrm{a}$ & $1.53 \mathrm{~b}$ & $332 \mathrm{a}$ \\
T5 & $14.65 \mathrm{~b}$ & $0.99 \mathrm{e}$ & $325 \mathrm{a}$ \\
\hline
\end{tabular}

Note: Different letter within a column indicate significant differences between means following Duncan Multiple Range Test $(\mathrm{P} \leq 0.05)$; ns, no significant differences $(\mathrm{P} \leq 0.05)$; nd, not determined. Control, (100\% soil); T1, ( $80 \%$ soil and $20 \%$ sewage sludge); $\mathrm{T} 2,(60 \%$ soil and $40 \%$ sewage sludge); $\mathrm{T} 3,(40 \%$ soil and $60 \%$ sewage sludge); T4, (20\% soil and $80 \%$ sewage sludge); T5, (100\% sewage sludge)

Table 2: Average dry weight biomass for leaves, stem and roots

\begin{tabular}{llll}
\hline Treatment & $\begin{array}{l}\text { Weight }(\mathrm{g}) \\
\text { Leaves }\end{array}$ & Stem & Roots \\
\hline Before & $35.00 \mathrm{~d}$ & $37.66 \mathrm{~d}$ & $45.83 \mathrm{c}$ \\
Control & $71.23 \mathrm{~b}$ & $63.48 \mathrm{~b}$ & $98.61 \mathrm{a}$ \\
T1 & $69.83 \mathrm{~b}$ & $61.70 \mathrm{~b}$ & $87.95 \mathrm{~b}$ \\
T2 & $44.27 \mathrm{c}$ & $50.00 \mathrm{c}$ & $82.71 \mathrm{~b}$ \\
T3 & $82.65 \mathrm{a}$ & $75.00 \mathrm{a}$ & $89.10 \mathrm{~b}$ \\
T4 & $46.56 \mathrm{c}$ & $65.07 \mathrm{~b}$ & $89.32 \mathrm{~b}$ \\
T5 & $84.71 \mathrm{a}$ & $60.84 \mathrm{~b}$ & $87.65 \mathrm{~b}$ \\
\hline
\end{tabular}

Note: Different letter within a column indicate significant differences between means following Duncan Multiple Range Test $(\mathrm{P} \leq 0.05)$; ns, no significant differences ( $\mathrm{P} \leq 0.05)$; nd, not determined. Control, (100\% soil); T1, ( $80 \%$ soil and $20 \%$ sewage sludge); $\mathrm{T} 2,(60 \%$ soil and $40 \%$ sewage sludge); T3, (40\% soil and $60 \%$ sewage sludge); T4, (20\% soil and $80 \%$ sewage sludge); T5, (100\% sewage sludge)

Table 3: Heavy metals concentration in growth medium of $O$. stamineus

\begin{tabular}{|c|c|c|c|c|c|c|}
\hline \multirow[b]{2}{*}{ Treatmen } & & \multirow[b]{2}{*}{$\mathrm{Zn}$} & \multicolumn{4}{|c|}{ Concentration (ppm) } \\
\hline & & & $\mathrm{Pb}$ & $\mathrm{Cr}$ & $\mathrm{Cu}$ & $\mathrm{Cd}$ \\
\hline \multirow[t]{2}{*}{ Control } & B & $10.50 \mathrm{a}$ & $1.04 \mathrm{c}$ & $1.15 \mathrm{a}$ & $1.01 \mathrm{c}$ & $0.02 \mathrm{c}$ \\
\hline & A & $2.76 \mathrm{~b}$ & $0.52 \mathrm{~d}$ & $1.12 b$ & $0.26 \mathrm{~d}$ & $0.00 \mathrm{c}$ \\
\hline \multirow[t]{2}{*}{$\mathrm{T} 1$} & B & $27.26 \mathrm{a}$ & $1.64 \mathrm{c}$ & $12.9 \mathrm{a}$ & $3.58 \mathrm{c}$ & $0.07 \mathrm{~d}$ \\
\hline & A & $23.27 \mathrm{~b}$ & $1.18 \mathrm{~d}$ & $3.12 \mathrm{~b}$ & $2.93 \mathrm{~d}$ & $0.06 \mathrm{~d}$ \\
\hline \multirow[t]{2}{*}{$\mathrm{T} 2$} & B & $36.80 \mathrm{a}$ & $1.43 \mathrm{c}$ & $2.69 \mathrm{a}$ & $2.79 \mathrm{c}$ & $0.09 \mathrm{a}$ \\
\hline & A & $31.73 b$ & $1.32 \mathrm{~d}$ & $2.94 \mathrm{~b}$ & $2.28 \mathrm{~d}$ & $0.04 \mathrm{~b}$ \\
\hline \multirow[t]{2}{*}{ T3 } & B & $46.50 \mathrm{a}$ & $2.00 \mathrm{c}$ & $2.45 \mathrm{a}$ & $8.90 \mathrm{c}$ & $0.07 \mathrm{e}$ \\
\hline & A & $40.59 \mathrm{~b}$ & $1.49 \mathrm{~d}$ & $1.86 \mathrm{~b}$ & $3.01 \mathrm{~d}$ & $0.05 \mathrm{e}$ \\
\hline \multirow[t]{2}{*}{$\mathrm{T} 4$} & B & $69.21 \mathrm{a}$ & $1.88 \mathrm{c}$ & $4.96 \mathrm{a}$ & $4.23 \mathrm{c}$ & $0.08 \mathrm{~b}$ \\
\hline & A & $65.88 \mathrm{~b}$ & $2.11 \mathrm{~d}$ & $7.29 b$ & $5.07 \mathrm{~d}$ & $0.08 \mathrm{~b}$ \\
\hline \multirow[t]{2}{*}{ T5 } & B & $290.05 \mathrm{a}$ & $5.33 \mathrm{c}$ & $23.45 \mathrm{a}$ & $17.07 \mathrm{c}$ & $0.18 \mathrm{a}$ \\
\hline & A & $252.04 \mathrm{~b}$ & $5.96 \mathrm{~d}$ & $24.40 \mathrm{~b}$ & $18.56 \mathrm{~d}$ & $0.13 b$ \\
\hline
\end{tabular}

Note: Different letter between soil before (B) and after (A) planting in each treatment for each element were significantly different following Duncan Multiple Range Test $(\mathrm{P} \leq 0.05)$. Control, $(100 \%$ soil); T1, (80\% soil and $20 \%$ sewage sludge); T2, $(60 \%$ soil and $40 \%$ sewage sludge); T3, (40\% soil and $60 \%$ sewage sludge); T4, (20\% soil and $80 \%$ sewage sludge); T5, (100\% sewage sludge) 
This shows that $\mathrm{Cd}$ concentration in the soil of treatment T5 had decreased by about $0.05 \mathrm{ppm}$. The control treatment gave the lowest $\mathrm{Cd}$ concentrations of $0.02 \mathrm{ppm}$ for before planting and $0.01 \mathrm{ppm}$ for after planting. This result also shows that the concentration of $5 \%$. Consequently, the growth of plant was good in treatment $\mathrm{T} 5$.

The results of $\mathrm{Cr}$ determination in the soil and sewage sludge before and after planting showed there were significant differences $(\mathrm{P} \leq 0.05)$. The concentrations of $\mathrm{Cr}$ in soil and sewage sludge before and after planting ranges from 1.15 to $23.45 \mathrm{ppm}$ and 1.12 to $24.30 \mathrm{ppm}$, respectively. Treatment $\mathrm{T} 5$ gave the highest $\mathrm{Cd}$ concentration with a value of $23.45 \mathrm{ppm}$ for after planting and $24.30 \mathrm{ppm}$ for before planting. The lowest concentration was given by the control treatment with respective values of 1.15 and $1.12 \mathrm{ppm}$ for before and after planting. From the results, T1 gave a conspicuous decrease of about $24 \%$. For $\mathrm{Cr}$, the concentration is nearly same for before and after planting because $\mathrm{Cr}$ is not taken up by plants. Treatments T2, T4 and T5 showed an increased concentration after planting $O$. stamineus. It is shows that this species could not uptake this element in high concentration. On the other hand, the height, basal diameter and number of leaves increment were the lowest in treatment T5. Reduction of germination, roots, shoots and leaves growth for a particular species (Barton et al., 2000).

The t-test analysis showed significant difference in $\mathrm{Zn}$ concentration before and after planting $(\mathrm{P} \leq 0.05)$. The lowest value was detected in the control treatment with a value of $10.50 \mathrm{ppm}$ for before planting and 2.76 ppm for after planting, while the highest concentration was recorded in T5 with 290.05 ppm and 252.04 ppm before and after planting, respectively. Moreover, the results showed that the plant was able to uptake $\mathrm{Zn}$ needed for its growth. The increasing acidity of soils may also liberate the bound pool of $\mathrm{Zn}$, leading initially to the increased concentration of free $\mathrm{Zn}$ ions in the soil solution. Several plant species, grasses and herbs included, are capable of tolerating $\mathrm{Zn}$ toxicity symptoms even at a relatively low $\mathrm{Zn}$ level (Pahlsson, 1989).

The results for $\mathrm{Cu}$ analysis showed that there were significant differences between before and after planting $(\mathrm{p} \leq 0.05)$. The concentrations of $\mathrm{Cu}$ in the soil and sewage sludge before and after planting ranges from 1.01 to $17.07 \mathrm{ppm}$ and 0.26 to $18.56 \mathrm{ppm}$, respectively. Treatment $\mathrm{T} 5$ has the highest $\mathrm{Cu}$ concentration in the planting media with a value of $17.07 \mathrm{ppm}$ before and $18.56 \mathrm{ppm}$ after planting; in the control it was $1.01 \mathrm{ppm}$ before and $0.26 \mathrm{ppm}$ after the planting period. The control, T1, T2 and T3 treatments showed reduction in $\mathrm{Cu}$ concentration because of plant uptake. However, T4 and T5 showed an increased $\mathrm{Cu}$ concentration where it increased from $0.84 \mathrm{ppm}$ to 1.49 ppm due to plant uptake. The excess of $\mathrm{Cu}$ may be stored in the planting medium.

The concentration of $\mathrm{Pb}$ differed significantly before and after planting $(\mathrm{P} \leq 0.05)$. The highest concentration was detected in T5 with a value of 5.33 ppm before and $5.96 \mathrm{ppm}$ after planting. The lowest concentrations were recorded in the control treatment with values of $1.04 \mathrm{ppm}$ and $0.52 \mathrm{ppm}$ before and after planting, respectively. It was found that sewage sludge has higher $\mathrm{Pb}$ content compared to the control and the $\mathrm{Pb}$ concentration increased with increasing percentage of sludge. Hence, $\mathrm{Pb}$ can be found easily in soils treated with sewage sludge.

Heavy metals concentration in $O$. stamineus plant parts: Table 4-6 showed the concentration of heavy metals in $O$. stamineus plant parts. These tables show the accumulation pattern of $\mathrm{Cd}$ concentration in plant parts. Cadmium concentration increased in the order of leaves $<$ stems $<$ roots. T1 recorded the highest $\mathrm{Cd}$ concentration in the leaves and the lowest $\mathrm{Cd}$ concentration was in T4. For stems, Cd concentration was the highest in the control treatment. The concentration of $\mathrm{Cd}$ in the roots was found to be lower compared to that in the leaves and stems, with a value of $0.01 \mathrm{ppm}$. Cadmium is not an element needed for plant growth. The movement of $\mathrm{Cd}$ in plant is limited and it is known that $\mathrm{Cd}$ is relatively more toxic to plants than $\mathrm{Pb}$.

In the case of $\mathrm{Cr}$ concentration in plant parts, the highest concentration was recorded in the leaves, while stems and roots showed lower concentration. For the control treatment, the highest concentration was in the leaves with a value of $8.48 \mathrm{ppm}$, while the lowest concentration was found in T5 with value of $0.52 \mathrm{ppm}$. For $\mathrm{T} 1, \mathrm{Cr}$ concentration was the highest in stems (1.15 ppm), while T5 gave the lowest concentration with a value of $0.08 \mathrm{ppm}$. In contrast, $\mathrm{Cr}$ concentration in roots was in the range of $0.11 \mathrm{ppm}$ to $0.47 \mathrm{ppm}$. There are many factors that affect these results. One of the factors was that the heavy metal was leached into the groundwater. It also depends on the local environment and soil factor. Toxic effects of $\mathrm{Cr}$ on plant include alteration in the germination process and reducing the growth of roots, stems and leaves. Hence, exposure of plant to high level of $\mathrm{Cr}$ decreases its dry matter production and yield. Chromium also causes deleterious 
Am. J. Applied Sci., 8 (4): 323-331, 2011

Table 4: Concentration of heavy metals in O. stamineus leaves Concentration (ppm)

\begin{tabular}{|c|c|c|c|c|c|}
\hline \multirow[b]{2}{*}{ Treatment } & \multirow[b]{2}{*}{$\mathrm{Zn}$} & \\
\hline & & $\mathrm{Pb}$ & $\mathrm{Cr}$ & $\mathrm{Cu}$ & $\mathrm{Cd}$ \\
\hline Control & $21.25 \mathrm{a}$ & $9.05 \mathrm{a}$ & $8.48 \mathrm{a}$ & $16.73 a$ & $0.01 \mathrm{a}$ \\
\hline $\mathrm{T} 1$ & $38.94 b$ & $3.77 \mathrm{c}$ & $2.09 \mathrm{~b}$ & $0.34 \mathrm{c}$ & $0.57 \mathrm{~b}$ \\
\hline $\mathrm{T} 2$ & $34.17 \mathrm{c}$ & $0.59 \mathrm{~d}$ & $0.92 \mathrm{c}$ & $0.57 \mathrm{c}$ & $0.02 \mathrm{a}$ \\
\hline T3 & $34.26 \mathrm{c}$ & $0.77 \mathrm{~d}$ & $1.14 \mathrm{c}$ & $1.33 \mathrm{~b}$ & $0.03 a$ \\
\hline $\mathrm{T} 4$ & $32.80 \mathrm{~d}$ & $8.00 \mathrm{~b}$ & $0.92 \mathrm{~d}$ & $0.50 \mathrm{c}$ & $0.01 \mathrm{a}$ \\
\hline T5 & $38.96 \mathrm{~b}$ & $0.88 \mathrm{~d}$ & $0.52 \mathrm{~d}$ & $1.09 \mathrm{~b}$ & $0.03 a$ \\
\hline
\end{tabular}

Note: Different letter within a column indicate significant differences between means following Duncan Multiple Range Test ( $\mathrm{P} \leq 0.05)$; ns, no significant differences $(\mathrm{P} \leq 0.05)$; nd, not determined. Control, (100\% soil); T1, (80\% soil and $20 \%$ sewage sludge); $\mathrm{T} 2,(60 \%$ soil and $40 \%$ sewage sludge); T3, ( $40 \%$ soil and $60 \%$ sewage sludge); T4, ( $20 \%$ soil and $80 \%$ sewage sludge); T5, (100\% sewage sludge)

Table 5: Concentration of heavy metals in O. stamineus stem

\begin{tabular}{lrrlll}
\hline & \multicolumn{5}{c}{ Concentration (ppm) } \\
Treatment & \multicolumn{1}{c}{$\mathrm{Zn}$} & \multicolumn{1}{c}{$\mathrm{Pb}$} & $\mathrm{Cr}$ & $\mathrm{Cu}$ & $\mathrm{Cd}$ \\
\hline Control & $31.03 \mathrm{~b}$ & $15.90 \mathrm{~b}$ & $0.48 \mathrm{~b}$ & $0.75 \mathrm{a}$ & $0.17 \mathrm{a}$ \\
T1 & $41.21 \mathrm{a}$ & $16.00 \mathrm{a}$ & $1.15 \mathrm{a}$ & $0.78 \mathrm{a}$ & $0.15 \mathrm{a}$ \\
T2 & $43.93 \mathrm{a}$ & $6.84 \mathrm{c}$ & $0.39 \mathrm{~b}$ & $0.33 \mathrm{~b}$ & $0.17 \mathrm{a}$ \\
T3 & $9.03 \mathrm{c}$ & $0.04 \mathrm{~d}$ & $0.13 \mathrm{~b}$ & $0.17 \mathrm{c}$ & $0.01 \mathrm{a}$ \\
T4 & $13.51 \mathrm{c}$ & $0.02 \mathrm{~d}$ & $0.09 \mathrm{~b}$ & $0.29 \mathrm{~b}$ & $0.01 \mathrm{a}$ \\
T5 & $8.26 \mathrm{c}$ & $0.01 \mathrm{~d}$ & $0.08 \mathrm{~b}$ & $0.13 \mathrm{c}$ & $0.01 \mathrm{a}$ \\
\hline
\end{tabular}

Note: Different letter within a column indicate significant differences between means following Duncan Multiple Range Test $(\mathrm{P} \leq 0.05)$; ns, no significant differences $(\mathrm{P} \leq 0.05)$; nd, not determined. Control, (100\% soil); T1, (80\% soil and $20 \%$ sewage sludge); T2, (60\% soil and $40 \%$ sewage sludge); T3, (40\% soil and $60 \%$ sewage sludge); T4, ( $20 \%$ soil and $80 \%$ sewage sludge); T5, (100\% sewage sludge)

Table 6: Concentration of heavy metals in O. stamineus roots

\begin{tabular}{llllll}
\hline & & Concentration (ppm) & & \\
\multicolumn{1}{l}{ Treatment } & $\mathrm{Zn}$ & $\mathrm{Pb}$ & $\mathrm{Cr}$ & $\mathrm{Cu}$ & $\mathrm{Cd}$ \\
\hline Control & $4.99 \mathrm{~d}$ & nd & $0.11 \mathrm{~b}$ & nd & $0.01 \mathrm{a}$ \\
T1 & $14.95 \mathrm{~b}$ & nd & $0.14 \mathrm{~b}$ & $0.17 \mathrm{~b}$ & $0.01 \mathrm{a}$ \\
T2 & $17.33 \mathrm{a}$ & nd & $0.10 \mathrm{~b}$ & $0.19 \mathrm{~b}$ & $0.01 \mathrm{a}$ \\
T3 & $9.63 \mathrm{c}$ & nd & $0.08 \mathrm{~b}$ & $0.19 \mathrm{~b}$ & $0.01 \mathrm{a}$ \\
T4 & nd & nd & $0.47 \mathrm{a}$ & $0.49 \mathrm{a}$ & $0.01 \mathrm{a}$ \\
T5 & $16.51 \mathrm{~b}$ & nd & $0.18 \mathrm{~b}$ & $0.27 \mathrm{a}$ & $0.01 \mathrm{a}$ \\
\hline
\end{tabular}

Note: Different letter within a column indicate significant differences between means following Duncan Multiple Range Test $(\mathrm{P} \leq 0.05)$; ns, no significant differences $(\mathrm{P} \leq 0.05)$; nd, not determined. Control, ( $100 \%$ soil); $\mathrm{T} 1,(80 \%$ soil and $20 \%$ sewage sludge); $\mathrm{T} 2,(60 \%$ soil and $40 \%$ sewage sludge); T3, (40\% soil and $60 \%$ sewage sludge); T4, ( $20 \%$ soil and $80 \%$ sewage sludge); T5, (100\% sewage sludge)

effects on plant physiological processes such as photosynthesis, water relations and mineral nutrition.

Zinc uptake by plant increased in the order of leaves $<$ stems $<$ roots. In this study it was shown that $\mathrm{T} 5 \mathrm{had}$ the highest concentration of $\mathrm{Zn}$ in the leaves, while the control treatment gave the lowest concentration of $21.25 \mathrm{ppm}$. For stems, the highest concentration was recorded in the T2 with a value of $41.21 \mathrm{ppm}$, while T5 showed the lowest concentration of $8.26 \mathrm{ppm}$. However, the concentration in the roots of
T5 was the highest with a value of $16.51 \mathrm{ppm}$, while T4 gave the lowest concentration of $\mathrm{Zn}(0 \mathrm{ppm})$. Zinc concentration was highly concentrated in the leaves, while stems and roots contained low amount. From previous study, it was found that $\mathrm{Zn}$ toxicity in plants limits the growth of both root and shoot (Fontes and Cox, 1998). Zinc toxicity also causes chlorosis in the younger leaves, which can extend to older leaves after exposure to high soil $\mathrm{Zn}$ level (Ebbs and Kochian, 1997). Excess $\mathrm{Zn}$ can also give rise to manganese (Mn) and copper $(\mathrm{Cu})$ deficiencies in plant shoots. Such deficiencies have been ascribed to hinder transfer of these micronutrients from roots to shoots. This hindrance is based on the fact that the $\mathrm{Fe}$ and $\mathrm{Mn}$ concentration in plants grown in Zn-rich media are greater in the roots than the shoots (Ebbs and Kochian, 1997).

Low amount of $\mathrm{Cu}$ was taken up by $\mathrm{O}$. stamineu because $\mathrm{Cu}$ is a micronutrient. The accumulation of $\mathrm{Cu}$ was in the order of leaves $<$ stems $<$ roots. The control treatment recorded the highest $\mathrm{Cu}$ concentration in the leaves. On the other hand, $\mathrm{Cu}$ concentration was high in the control medium with a value of $16.73 \mathrm{ppm}$, while $\mathrm{T} 1$ recorded the lowest concentration in the leaves $(0.34$ ppm). Copper concentration in the stems ranges from $0.13 \mathrm{ppm}$ to $0.78 \mathrm{ppm}$. The highest concentration was recorded in T1 (80\% soil: $20 \%$ sewage sludge) and the lowest concentration was recorded in T5. The concentration of $\mathrm{Cu}$ in the roots was found to be lower compared to that in the leaves and stems, ranging 0.11 $\mathrm{ppm}$ to $0.49 \mathrm{ppm}$. Usually, visible symptoms of heavy metal toxicity, like that of $\mathrm{Cu}$, are small chlorotic leaves and early leaf fall. As a result the growth of plant is stunted and initiation of roots and development of root laterals are poor. The reduction in root development may result in a lower water and nutrient uptake, leading to disturbances in the metabolism and growth retardations. A study carried out by Sánchez-Martin et al. (2004) on total heavy metal content in a soil treated with sludge showed a slight increase in $\mathrm{Pb}, \mathrm{Cu}$ and $\mathrm{Ni}$ concentration in plant parts.

For the control treatment, the highest $\mathrm{Pb}$ concentration was in the leaves. We found that only a small amount of $\mathrm{Pb}$ was taken up by plant. Plant accumulated $\mathrm{Pb}$ in the order of leaves $<$ stems $<$ roots. Lead concentration was high in the control medium. For $\mathrm{T} 1$, the lowest concentration of $\mathrm{Pb}$ was in the leaves. The $\mathrm{Pb}$ concentration in the stems ranges from $0.01 \mathrm{ppm}$ to $16.00 \mathrm{ppm}$. The highest concentration was recorded in T1, while the lowest concentration was recorded in $\mathrm{T} 5$. 
Relationship between heavy metals concentration in the soil and in plant parts: The concentration of $\mathrm{Cd}$ and $\mathrm{Pb}$ in the stem was correlated with those in the soil. Their concentration in the soil increased in the order of order of $\mathrm{Cd}<\mathrm{Pb}<\mathrm{Cu}<\mathrm{Cr}<\mathrm{Zn}$. Their concentration was higher in the leaves than either stems or roots. The accumulation pattern in the leaves was in the order of $\mathrm{Cd}<\mathrm{Cr}<\mathrm{Cu}<\mathrm{Pb}<\mathrm{Zn}$. Studies carried out by Kim et al. (2003) showed almost similar findings. They also confirmed that the phytoextraction coefficients increased in the order $\mathrm{Pb}<\mathrm{Cu}<\mathrm{Zn}<\mathrm{Cd}$. Therefore, more $\mathrm{Pb}$ and $\mathrm{Zn}$ are taken up by plant than that of $\mathrm{Cd}$. These heavy metals are transported from roots to the different parts of the plant. Greger (2004) found that Cd and $\mathrm{Zn}$ were more mobile than $\mathrm{Cu}$ and $\mathrm{Pb}$.

This study found that the concentration of the heavy metals in the soil was correlated with those in the stem. This is in contrast with the study of Baye et al. (2008) who found that there was no correlation between bioaccumulation $\mathrm{Cd}$ by medicinal plants and its concentration in soil. The presence of $\mathrm{Cd}$ in plant at high level may cause a decrease in photosynthesis and the uptake of water and nutrients (Mohanpuria et al., 2007). However, the concentration of Cd normally encountered in the environment does not cause acute toxicity. Waldron (1980) showed that major hazard to human health from $\mathrm{Cd}$ is its chronic accumulation in the kidney cortex.

The $\mathrm{Cr}$ concentration was nearly same before and after planting and this could be due to non-essentiality of Cr by plant (Sánchez-Martin et al., 2004; Shanker et al., 2005). High level of $\mathrm{Cr}$ may cause serious environmental contamination in soils, sediments and groundwater (Shanker et al., 2005). In this study no correlation was found between $\mathrm{Cr}$ in the soil and plant parts. This is agreement with the finding of Bowen (1979) who found that the concentration in leaves parts of plants showed little relationship with the overall the content of $\mathrm{Cr}$ in the soils.

Plant can uptake $\mathrm{Cu}$ which is a micronutrient (Thomas et al., 1998). Our study found that $\mathrm{Cu}$ concentration in the soil was highest in T5. Excessive uptake of $\mathrm{Cu}$ may cause plant injury (Lewis et al., 2001). No correlation was found between $\mathrm{Cu}$ in plant parts and that in soil.

Our results showed that soil $\mathrm{Pb}$ was highest in $\mathrm{T} 4$, while that for plant part it was T5. Sánchez-Martin et al. (2004) believed that $\mathrm{Pb}$ present in sludge did not give rise to its increase in plant unless the concentration was very high.

\section{CONCLUSION}

The O. stamineus was found to have the ability or potential to vanish the toxicity of heavy metals especially $\mathrm{Zn}$ in leaves (38.96 ppm). Besides that, $O$. stamineus absorbed heavy metals and stored it at various plant parts (leaves, stems and roots) in the range of $0.01 \mathrm{ppm}$ to $0.57 \mathrm{ppm}$ for $\mathrm{Cd}, 0.08$ to $8.48 \mathrm{ppm}$ for $\mathrm{Cr}, 0 \mathrm{ppm}$ to $43.93 \mathrm{ppm}$ for $\mathrm{Zn}, 0.11$ to $16.73 \mathrm{ppm}$ for $\mathrm{Cu}$ and 0.01 to $9.05 \mathrm{ppm}$ for $\mathrm{Pb}$. This plant species can be considered as a good phytoremediator to absorb heavy metals of contaminated soils, especially zinc. Further studies on the possibility of $O$. stamineus planted in soil containing with sewage sludge to be commercialized as food product needs to be done to evaluate the safety and hazardous to human health.

\section{ACKNOWLEDGEMENT}

This research was financially supported by a Fundamental Research Grant Scheme (FRGS) from the Ministry of Higher Education of Malaysia (MOHE) through the Universiti Putra Malaysia, Malaysia (UPM). We thank Ms. Zarina Abdul Rahman and Mr. Ariffin Abu Hassan for their kind assistance during the laboratory analysis at the laboratory of Soil Science, Faculty of Forestry and Faculty of Agriculture, Universiti Putra Malaysia. We also acknowledge the Indah Water Konsortium (IWK) for their permission to use the sewage sludge in this study.

\section{REFERENCES}

Affendy, H., M. Aminuddin, A. Arifin, M. Mandy and K. Julius et al., 2010. Effects of light intensity on Orthosiphon stamineus Benth. Seedlings treated with different organic fertilizers. Int. J. Agricultural Res., 5: 201-207.

Ahmadpour, P., A.M. Nawi, A. Abdu, H. Abdul-Hamid and D.K. Singh et al., 2010. Uptake of heavy metals by Jatropha curcas L. planted in soils containing sewage sludge. Am. J. Applied Sci., 7: 1291-1299. DOI: 10.3844/ajassp.2010.1291.1299

Arifin, A., S. Tanaka, S. Jusop, Z. Ibrahim and D. Hattori et al., 2007. Soil characteristics under rehabilitation of degraded forestland in Perak, Peninsular Malaysia. Pedologist, 51: 76-88.

Bahmanyar, M.A. and H. Piradshti, 2008. Responses of biomass, chlorophyll and macro- and micronutrient uptake of rice (Oryza sativa L.) to organic and chemical fertilizers. Australian Society of Agronomy. http://regional.org.au/au/asa/2008/poster/farmerfocussed-research/5773_bahmanya.htm 
Barton, L.L., G.V. Johnson, A.G. O’Nan and B.M. Wagener. 2000. Inhibition of ferric chelate reductase in alfalfa roots by cobalt, nickel, chromium, and copper. J. Plant Nutr., 23: 1833-1845. DOI: $10.1080 / 01904160009382146$

Baye, J., S. Nair and P. Kakkar, 2008. Heavy metal accumulation in medicinal plants collected from environmentally different sites. Biomed. Environ. Sci., 21: 319-324. DOI: 10.1016/S08953988(08)60049-5

Bowen, H.J.M., 1979. Environmental Chemistry of the Elements. 1st Edn., Academic Press, USA., ISBN10: 0121204502 , pp: 333.

Canet, R., F. Pomares and F. Tarazona, 1997. Chemical extractability and availability of heavy metals after seven years application of organic wastes to a citrus soil. Soil Use Manag., 13: 117-121. DOI: 10.1111/j.1475-2743.1997.tb00569.x

Chin, J.H., H.H. Abas and I. Sabariah, 2007. Toxicity study of orthosiphon stamineus benth (misai kucing) on sprague dawley rats. Trop. Biomed., 25: 9-16. PMID: 18600199

Ebbs, S.D. and L.V. Kochian. 1997. Toxicity of zinc and copper to Brassica species : Implications for phytoremediation. J. Environ. Q., 26: 776-781.

Fontes, R.L.S. and F.R. Cox, 1998. Zinc toxicity in soybean grown at high iron concentration in nutrient solution. J. Plant Nutr., 21: 1723-1730. DOI: 10.1080/01904169809365517

Greger, M., 2004. Metal availability, uptake, transport and accumulation in plants. In: Heavy Metal Stress in Plants from Biomolecules to Ecosystem, M.N.V. Prasad (Ed.). Springer, USA., ISBN-10: 354040138, pp: 1-27.

Heiri, O., A.F. Lotter and G. Lemcke. 2001. Loss on ignition as a method for estimating organic and carbonate content in sediments: reproducibility and comparability of results. J. Paleolimnol., 25: 101-110.

Heppner, J.B., 1993. Citrus leaf miner. University of Florida. IFAS Extension. http://polkhort.ifas.ufl.edu/documents/publications/ Citrus\%20Leafminer.pdf

Jamil, S., P.C. Abhilash, N. Singh and P.N. Sharma, 2009. Jatropha curcas: A potential crop for phytoremediation of coal fly ash. J. Hazard. Mat., 172: 269-275. DOI: 10.1016/j.jhazmat.2009.07.004

Jones, K.C. and A.E. Johnson, 1989. Cadmium in cereal grain and herbage from long-term experimental plots at Rothamsted, UK. Environ. Poll., 57: 199-216. DOI: 10.1016/02697491(89)90012-2
Kabata-Pendias, A. and H. Pendias, 2001. Trace Elements in the Soil and Plants. 3rd Edn., CRC Press, USA., ISBN-10: 0849315751, pp: 413.

Kim, I.S., K.H. Kang, P. Johnson-Green and E.J. Lee. 2003. Investigation of heavy metal accumulation in Polygonum thunbergii for phytoextraction. Environ. Poll., 126: 235-243. DOI: 10.1016/S02697491(03)00190-8

Korentajer, L., 1991. A review of the agricultural use of sewage sludge. Benefits and potential hazards. Water Air Soil Pollut., 17: 189-196.

Leng, L.W. and C. Lai-Keng, 2003. Plant regeneration from stem nodal segments of Orthosiphon stamineus Benth., a medicinal plant with diuretic activity. In Vitro Cell. Dev. Biol.-Plant, 40: 115-118. DOI: $10.1079 /$ IVP2003500

Lewis, S., M.E. Donkin and M.H. Depledge, 2001. HSP70 expression in Enteromorpha intestinalis (Chlorophyta) exposed to environmental stressors. Aqua. Toxicol., 51: 277-291. PMID: 11090890

Meagher, R.B., 2000. Phytoremediation of toxic elemental and organic pollutants. Curr. Opinion Plant Biol., 3: 153-162. DOI: 10.1016/S13695266(99)00054-0

Mohanpuria, P., N.K. Rana and S.K.Yadav, 2007. Cadmium induced oxidative stress influence on glutathione metabolic genes of Camellia sinensis (L.) O. Kuntze. Environ. Toxicol., 22: 368-374. DOI: $10.1002 /$ tox.20273

Pahlsson, A.M.B., 1989. Toxicity of heavy metals (Zn, $\mathrm{Cu}, \mathrm{Cd}, \mathrm{Pb})$ to vascular plants. Water, Air Soil Poll., 47: 287-319. DOI: 10.1007/BF00279329

Rice, C.W., 2002. Storing carbon in soil: Why and how? Geo Times. http://www.agiweb.org/geotimes/jan02/feature_car bon.html

Sánchez-Martin, M. Garcia-Delgado, L.F. Lorenzo and M. Sanchez-Camazano. 2004. Heavy metal distribution in sewage sludge-treated soil profiles. Water Contaminant: Lifecycle and Entry into Food Chain.

http://www.ramiran.net/doc04/Proceedings\%2004/ Sanchez_Martin.pdf

Schnoor, J.L., L.A. Light, S.C. McCutcheon, N.L. Wolfe and L.H. Carreira, 1995. Phytoremediation of organic and nutrient contaminants. Environ. Sci. Technol., 29: 318-223. DOI: 10.1021/es00007a002

Shanker, A. K., C. Cervantes, H. Loza-Tavera and S. Avudainayagam, 2005. Chromium toxicity in plants. Environ. Int., 31: 739-753. DOI: 10.1016/j.envint.2005.02.003 
Singh, R.P. and M. Argawal. 2007. Potential benefits and risks of land application of sewage sludge. J. Waste Manage., 89: 347-358. DOI: 10.1016/j.wasman.2006.12.010

Thomas, J.C., F.K. Malick, C. Endreszl, E.C. Davies and S. Kent, 1998. Distinct responses to copper stress in the halophyte Mesembryanthemum crystallinum. Phys. Plantarum, 102: 360-368. DOI: $10.1034 / \mathrm{j} .1399-3054.1998 .1020304 . x$
Waldron, H.A., 1980. Metals in the Environment. 1st Edn., Academic Press, USA., ISBN-10: 012731850X, pp: 333. 